\title{
Virtual cooperativity in myoglobin oxygen saturation curve in skeletal muscle in vivo Akitoshi Seiyama*
}

Address: Division of Physiology and Biosignaling, Osaka University Graduate School of Medicine, 2-2 Yamadaoka, Suita, Osaka 565-0871, Japan Email: Akitoshi Seiyama* - aseiyama@phys1.med.osaka-u.ac.jp

* Corresponding author

Published: 24 January 2006

Dynamic Medicine 2006, 5:3 doi:10.1/86/1476-59/8-5-3

This article is available from: http://www.dynamic-med.com/content/5/I/3

(c) 2006 Seiyama; licensee BioMed Central Ltd.

This is an Open Access article distributed under the terms of the Creative Commons Attribution License (http://creativecommons.org/licenses/by/2.0), which permits unrestricted use, distribution, and reproduction in any medium, provided the original work is properly cited.
Received: 23 June 2005

Accepted: 24 January 2006

\begin{abstract}
Background: Myoglobin (Mb) is the simplest monomeric hemoprotein and its physicochemical properties including reversible oxygen $\left(\mathrm{O}_{2}\right)$ binding in aqueous solution are well known. Unexpectedly, however, its physiological role in intact muscle has not yet been established in spite of the fact that the role of the more complex tetrameric hemoprotein, hemoglobin $(\mathrm{Hb})$, in red cells is well established. Here, I report my new findings on an overlooked property of skeletal Mb.

Methods: I directly observed the oxygenation of $\mathrm{Mb}$ in perfused rat skeletal muscle under various states of tissue respiration. A computer-controlled rapid scanning spectrophotometer was used to measure the oxygenation of $\mathrm{Mb}$ in the transmission mode. The light beam was focused on the thigh (quadriceps) through a 5-mm-diameter light guide. The transmitted light was conducted to the spectrophotometer through another 5-mm-diameter light guide. Visible difference spectra in the range of 500-650 nm were recorded when $\mathrm{O}_{2}$ uptake in the hindlimb muscle reached a constant value after every stepwise change in the $\mathrm{O}_{2}$ concentration of the buffer.

Results: The $\mathrm{O}_{2}$ dissociation curve (ODC) of $\mathrm{Mb}$, when the effluent buffer $\mathrm{O}_{2}$ pressure was used as the abscissa, was of a sigmoid shape under normal and increased respiratory conditions whereas it was of rectangular hyperbolic shape under a suppressed respiratory condition. The dissociation curve was shifted toward the right and became more sigmoid with an increase in tissue respiration activity. These observations indicate that an increase in $\mathrm{O}_{2}$ demand in tissues makes the $\mathrm{O}_{2}$ saturation of $\mathrm{Mb}$ more sensitive to $\mathrm{O}_{2}$ pressure change in the capillaries and enhances the Mbmediated $\mathrm{O}_{2}$ transfer from $\mathrm{Hb}$ to cytochrome oxidase $\left(\mathrm{Cyt} . \mathrm{aa}_{3}\right)$, especially under heavy $\mathrm{O}_{2}$ demands.
\end{abstract}

Conclusion: The virtual cooperativity and $\mathrm{O}_{2}$ demand-dependent shifts of the ODC may provide a basis for explaining why Mb has been preserved as monomer during molecular evolution.

\section{Background}

$\mathrm{Mb}$ is a monomeric hemoprotein with a molecular weight of $17 \mathrm{kDa}$, carrying a single oxygen $\left(\mathrm{O}_{2}\right)$-binding site per molecule. It is located near the contractile elements and cell membranes in the red skeletal and cardiac muscles of vertebrates [1]. Previously, Millikan [2,3] proposed the following three possible physiological functions for $\mathrm{Mb}$ : (a) an $\mathrm{O}_{2}$ store during temporary deficits in $\mathrm{O}_{2}$ supply, (b) an intracellular $\mathrm{O}_{2}$ transport agent and (c) an intracellular catalyst. Among them, the first function has traditionally 


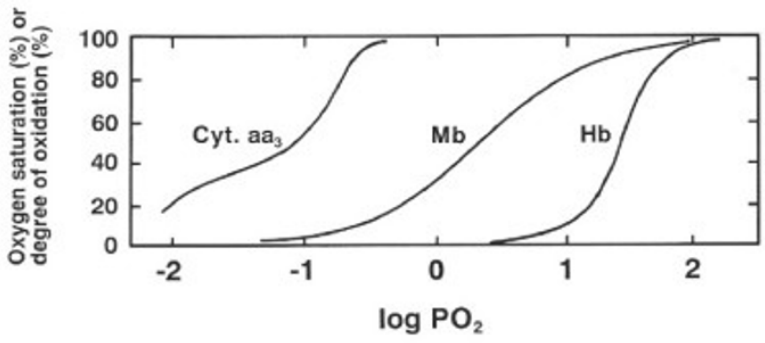

Figure I

Oxygen dissociation curves (ODCs) for $\mathrm{Hb}$ (whole blood) and $\mathrm{Mb}$ and oxidation curve for $\mathrm{Cyt} . \mathrm{aa}_{3}\left(\right.$ at $\left.37^{\circ} \mathrm{C}\right) . \mathrm{PO}_{2}$, partial pressure of oxygen in $\mathrm{mmHg}$. Data from Imai [36].

been accepted. In the muscles of a beating heart and exercising skeletal muscles, $\mathrm{Mb}$ acts as a short-term $\mathrm{O}_{2}$ store (i.e., an $\mathrm{O}_{2}$ buffer), tiding the muscles over from one contraction to the next. The rich $\mathrm{Mb}$ content in skeletal muscles in aquatic mammals is considered to provide a longterm $\mathrm{O}_{2}$ store during diving. However, this role of $\mathrm{Mb}$, at least in human, is not significant because its oxygen storage capacity is so low that the total oxygen bound to $\mathrm{Mb}$ is exhausted within ca. $5.5 \mathrm{~s}$ after being cut off from the $\mathrm{O}_{2}$ supply [4]. The second function, called "facilitated $\mathrm{O}_{2}$-diffusion by $\mathrm{Mb} "$, was based on findings in in vitro experiments $[5,6]$. The conditions required for this facilitated diffusion to occur are [7]: (a) existence of deoxygenated $\mathrm{Mb}$ in a certain fraction (or certain low intracellular partial pressure of $\mathrm{O}_{2}$ ), (b) existence of a spatial gradient of oxygenated $\mathrm{Mb}$ concentration as a driving force for translational diffusion of $\mathrm{Mb}$, and (c) sufficient mobility of the oxygenated $\mathrm{Mb}$ to permit diffusion. Although this mechanism has been widely accepted, several discrepancies remain unresolved [8-12]. As for the third function, Doeller and Wittenberg [13] proposed the occurrence of Mbmediated oxidative phosphorylation in heart myocytes under aerobic conditions. However, Mb concentration is not closely related to the oxidative capacity of muscles, that is, the concentration is higher in skeletal muscles ( $\sim 0.5 \mathrm{mmole} / \mathrm{kg}$ wet wt.) than in heart muscles $(\sim 0.25$ mmole/kg wet wt.) [7].

Thus, the physiological roles of $\mathrm{Mb}$ have not yet been established. Recently, alternative functions of (d) $\mathrm{O}_{2}$ sensing and (e) nitric oxide scavenging were proposed [14]. Another recent paper [15] seemed to have totally scrambled the past long-term disputes about the physiological significance of $\mathrm{Mb}$. It was shown using gene-knockout technology that mice without $\mathrm{Mb}$ are fertile, exhibit normal exercise capacity, and have a normal ventilatory response to low $\mathrm{O}_{2}$ levels, suggesting that $\mathrm{Mb}$ is not essential for apparently normal cardiovascular and musculoskeletal function in a terrestrial, homoiothermic mammal. However, it has been reported that the disruption of $\mathrm{Mb}$ results in the activation of multiple compensatory mechanisms such as increases in $\mathrm{Hb}$ concentration, hematocrit, coronary flow, coronary reserve, and capillary density [16]. Further, a Mb-like hemoprotein, neuroglobin, has been found in the vertebrate brain [17] contrary to the long-held belief that $\mathrm{Mb}$ is restricted to vertebrate cardiomyocytes and oxidative skeletal myofibers. These studies imply that further investigations are required to reveal the physiological role of $\mathrm{Mb}$ in intact organs.

In contrast to $\mathrm{Mb}$, which shows a rectangular hyperbolic $\mathrm{ODC}$, the vertebrate $\mathrm{Hb}$, a tetramer carrying four $\mathrm{O}_{2}$ binding sites, shows a sigmoid ODC that is described in terms of a four-step cooperative $\mathrm{O}_{2}$ binding. It is widely accepted that the sigmoid ODC enables $\mathrm{Hb}$ to transport $\mathrm{O}_{2}$ with high efficiency: it is nearly fully saturated with $\mathrm{O}_{2}$ in the lungs and it unloads $\mathrm{O}_{2}$ sensitively depending on decreases in the partial pressure of oxygen $\left(\mathrm{PO}_{2}\right)$ in peripheral tissues. Here, no convincing explanation has been given for the question: does the hyperbolic ODC of Mb have any physiological adequacy or reasonability? The Bohr effect of $\mathrm{Hb}$ ( $\mathrm{pH}$ dependence of $\mathrm{O}_{2}$ affinity) has physiological significance, in that it enhances $\mathrm{O}_{2}$ unloading from $\mathrm{Hb}$ in the capillaries where $\mathrm{pH}$ tends to decrease and in that it increases the solubility of $\mathrm{CO}_{2}$ as bicarbonate in the venous blood through deoxygenation-induced uptake of protons by $\mathrm{Hb}$. In contrast, Mb lacks the Bohr effect and it had long been believed that Mb was a totally non-allosteric protein, although recently lactate, a metabolic product, was found to cause a right-shift of the ODC for horse and sperm whale Mbs [18].

It is well established that the $\mathrm{O}_{2}$ affinity of $\mathrm{Mb}$ is higher than that of $\mathrm{Hb}$ but lower than that of Cyt. $\mathrm{aa}_{3}$, as known from the relative positions of the ODCs for $\mathrm{Mb}$ and $\mathrm{Hb}$ and the oxidation curve for Cyt. $\mathrm{aa}_{3}$ (Fig. 1). This fact led one to the idea that $\mathrm{Mb}$ acts as an intracellular $\mathrm{O}_{2}$ transfer agent from $\mathrm{Hb}$ (vascular space) to Cyt. aa3 (mitochondria). Here, one must not overlook an important fact. The three curves in Fig. 1 are drawn with the same $\mathrm{PO}_{2}$ scale. Therefore, they give $\mathrm{O}_{2}$ saturation $(\mathrm{Y})$ or the degree of oxidation for the individual proteins when dissolved in the same solution and are in equilibrium with oxygen at the given $\mathrm{PO}_{2}$ value. However, in vivo, they sense different $\mathrm{PO}_{2}$ values due to the presence of a $\mathrm{PO}_{2}$ gradient along the path from the inside of red cells to the mitochondria in myocytes. Thus, the relative positions of the three curves in Fig. 1 must be considered with this precaution, and direct in vivo observations of $\mathrm{Y}$ or the degree of oxidation for these three individual proteins are required to get insight into their ensemble functional roles. Recently, using ${ }^{1} \mathrm{H}$ nuclear magnetic resonance spectroscopy, Mole et al. [19] and Richardson et al. [20] directly observed Y 


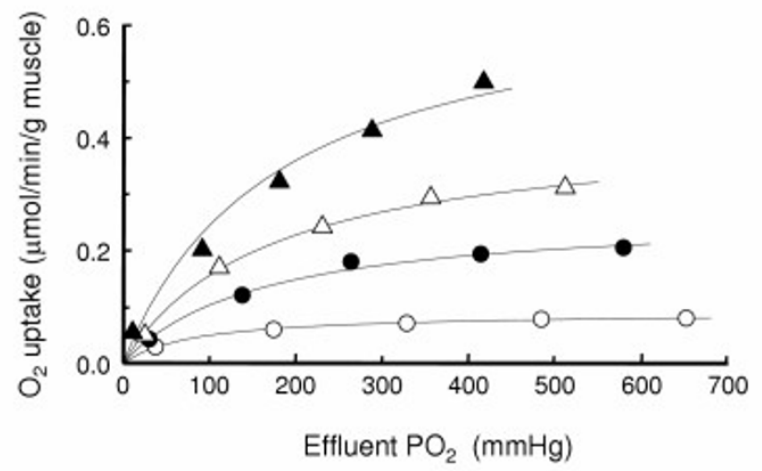

Figure 2

Steady-state $\mathrm{O}_{2}$ uptake rate $(\mathrm{V})$ of perfused rat hindlimb muscles as a function of effluent buffer $\mathrm{PO}_{2}$. The rat hindlimb was perfused with Krebs-bicarbonate buffers containing no additive $(\bigcirc)$ as control, $0.4 \mathrm{mM}$ of $\mathrm{KCN}(\bigcirc)$ for suppression of muscle respiration, and $5 \mu \mathrm{M}(\triangle)$ or $10 \mu \mathrm{M}(\mathbf{\Delta})$ 2,4-dinitrophenol for stimulation of muscle respiration. Symbols express observed points. Each plot is the mean of experiments using three animals, and the errors for each data point are less than the size of symbols. The solid lines were calculated using a rectangular hyperbolic curve: $\mathrm{V}=\mathrm{V}_{\max }\left(\mathrm{PO}_{2} /\right.$ $\left.\mathrm{P}_{\mathrm{V} 50}\right) /\left\{\mathrm{I}+\left(\mathrm{PO}_{2} / \mathrm{P}_{\mathrm{V} 50}\right)\right\}$. The values of $\mathrm{P}_{\mathrm{V} 50}$ and $\mathrm{V}_{\max }$ are given in Table I which also includes the maximal values of influent and effluent $\mathrm{PO}_{2}$.

for $\mathrm{Mb}$ in human skeletal muscles under exercise of different intensities or during breathing of air with different $\mathrm{O}_{2}$ contents. In these studies, $\mathrm{Mb}$ was used as an indicator of intracellular $\mathrm{PO}_{2}$, and no attention was paid to the relation between $\mathrm{Mb}$ saturation and capillary $\mathrm{PO}_{2}$.

In the present study, we directly measured $\mathrm{Y}$ for $\mathrm{Mb}$ in isolated rat hindlimb muscles, perfused with a Hb-free medium, under vigorous changes in respiration conditions. We plotted the $\mathrm{Y}$ values as a function of buffer $\mathrm{PO}_{2}$ and found that the apparent ODC thus plotted for skeletal muscle $\mathrm{Mb}$ was rectangular hyperbolic under a suppressed metabolic activity condition but it became sigmoid under enhanced metabolic activity conditions, realizing virtually cooperative $\mathrm{O}_{2}$ binding by monomeric $\mathrm{Mb}$.

\section{Methods}

\section{Muscle perfusion}

All experimental procedures were performed according to the institutional guidelines for animal care and use of the Committee for Animal Care of Osaka University and the Japanese Physiological Society. Male Wistar rats (250 to $300 \mathrm{~g}$ body weight, $\mathrm{N}=12$ ) fed on a commercial diet were used. Rats were anesthetized with sodium pentobarbital (30 mg/kg body wt., intraperitoneal injection). Prepara-
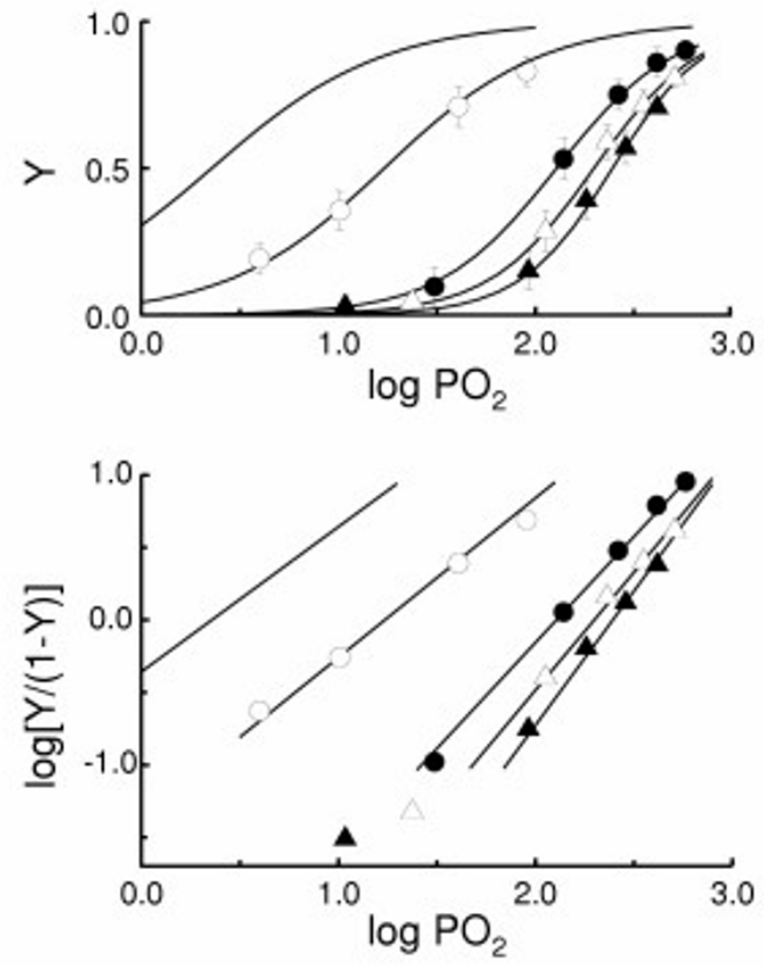

Figure 3

Apparent ODCs for $\mathrm{Mb}$ in perfused muscle at various steady-state $\mathrm{O}_{2}$ uptake levels. $\mathrm{PO}_{2}$ is the same as in Fig. 2. A, ODCs as $\mathrm{O}_{2}$ saturation ( $Y$ ) plotted against log $\mathrm{PO}_{2}$. The lines were calculated from the Hill equation (see below). Each ODC was obtained from three animals (three muscle preparations). Symbols (mean $\pm \mathrm{SD}$ ) express observed points and their meaning is the same as in Fig. 2. The lines without symbols are the ODCs for $\mathrm{Mb}$ in non-respiring muscle [2I]. B, Apparent ODCs as expressed by the Hill plot which is based on the linearized Hill equation [25]: $\log \{Y /(I-Y)\}=n(\log$ $\left.\mathrm{PO}_{2}-\log \mathrm{P}_{\mathrm{Y} 50}\right)$. The slope of the plot (n) was constant and expressed as $\mathrm{n}_{\text {app }}$ in the present paper. The $\mathrm{n}_{\text {app }}$ and intercept values obtained from the Hill plots are listed in Table 2.

tion of the isolated rat hindlimb and the perfusion apparatus were described previously [21,22]. Surgery was modified from those of Ruderman et al. [23] and Shiota et al. [24]. After a midline abdominal incision, the superficial epigastric vessels were ligated. The abdominal wall was then incised from the pubic symphysis to the xiphoid process. The spermary, testis, and inferior mesenteric arteries and veins were ligated, and the spermaries, the testises, and part of the descending colon were excised, together with contiguous adipose tissue. The caudal artery and internal iliac artery and vein were also ligated. Ligature were placed around the neck of the bladder, the coagulating gland and the prostate gland. While carefully 
Table I: Values of muscle perfusion parameters and Mb oxygenation parameters in various tissue respiration states

\begin{tabular}{lcccc}
\hline Respiration state: & Suppressed $(0.4 \mathrm{mM} \mathrm{KCN})$ & Control & Enhanced $(5 \mu M$ DNPa $)$ & Enhanced (I0 $\mu M$ DNP) \\
\hline Influent $\mathrm{PO}_{2}$ & 700 & 700 & 700 & 700 \\
Effluent $\mathrm{PO}_{2}$ & $652 \pm 14$ & $579 \pm 6$ & $512 \pm 15$ & $418 \pm 18$ \\
$\mathrm{~V}_{\max } \mathrm{b}$ & 0.09 & 0.27 & 0.42 & 0.68 \\
$\mathrm{P}_{\mathrm{V} 50}{ }^{\mathrm{c}}$ & 83 & 160 & 170 & 180 \\
\hline
\end{tabular}

a, 2,4-dinitorophenol; b, Maximal value of steady-state $\mathrm{O}_{2}$ uptake rate $(\mathrm{V})$ at infinite influent $\mathrm{PO}_{2}$ (in $\mu \mathrm{mol} / \mathrm{min} / \mathrm{g}$ muscle); $c$, effluent $P \mathrm{P}_{2}$ at $\mathrm{V}=$ half $\mathrm{V}_{\max }$ (in $\mathrm{mmHg}$ ). Values of $\mathrm{V}_{\max }$ and $\mathrm{P}_{\mathrm{V} 50}$ were obtained from solid lines shown in Figure 2.

removing the skin covering the lower half of the animal, the vessels that supply the subcutaneous region were ligated. Then, the inferior epigastric, iliolumbar and renal arteries and veins were ligated as well as the coeliac axis and portal vein. Further, a ligature was also placed around the tail. A hemoglobin-free Krebs-bicarbonate buffer ( $\mathrm{NaCl}, 115 \mathrm{mM} ; \mathrm{KCl}, 5.9 \mathrm{mM} ; \mathrm{MgCl}_{2}, 1.2 \mathrm{mM} ; \mathrm{NaH}_{2} \mathrm{PO}_{4}$, $1.2 \mathrm{mM} ; \mathrm{Na}_{2} \mathrm{SO}_{4}, 1.2 \mathrm{mM} ; \mathrm{NaHCO}_{3}, 25 \mathrm{mM} ; \mathrm{CaCl}_{2}, 2.5$ $\mathrm{mM}$; glucose, $10 \mathrm{mM}$; $\mathrm{pH} 7.4)$ containing $4 \%(\mathrm{w} / \mathrm{v})$ polyvinylpyrrolidone (PVP-40T; average M.W., 40,000; Sigma) was perfused from the abdominal aorta in the flow-through mode at a constant flow rate of $1.0 \mathrm{ml} / \mathrm{min} /$ g muscle. Perfusate and muscle temperature were maintained at $25 \pm 0.5^{\circ} \mathrm{C}$. The effluent was collected from the inferior vena cava in order to measure the $\mathrm{O}_{2}$ uptake rate. $\mathrm{PO}_{2}$ in the influent and the effluent buffers was monitored with an oxygen electrode. The rate of $\mathrm{O}_{2}$ uptake was calculated from the flow rate and the difference in $\mathrm{O}_{2}$ concentration between the influent and the effluent buffers. Before each measurement, the rat hindlimb was perfused with the buffer equilibrated with $95 \% \mathrm{O}_{2}+5 \% \mathrm{CO}_{2}$ for 30 min. Then, the $\mathrm{O}_{2}$ concentration in the perfusate was decreased stepwise by mixing a buffer equilibrated with $95 \% \mathrm{O}_{2}+5 \% \mathrm{CO}_{2}$ and another equilibrated with $95 \% \mathrm{~N}_{2}$ $+5 \% \mathrm{CO}_{2}$, and the measurement was started. As required, potassium cyanide or 2,4-dinitrophenol was infused to modify the $\mathrm{O}_{2}$ uptake rate of the perfused muscle. During each measurement of about $60 \mathrm{~min}$, the perfusion pressure remained nearly constant at 73-78 mmHg. All chemicals used were of analytical reagent grade.

\section{Spectrophotometric measurement of myoglobin oxygenation}

A computer-controlled rapid scanning spectrophotometer (USP-501, Unisoku, Osaka, Japan) was used to measure the oxygenation of $\mathrm{Mb}$ in the transmission mode $[21,22]$. The light beam was focused on the thigh (quadriceps) through a 5-mm-diameter light guide. The transmitted light was conducted to the spectrophotometer through another 5-mm-diameter light guide. Visible difference spectra in the range of 500-650 $\mathrm{nm}$ were recorded when $\mathrm{O}_{2}$ uptake in the hindlimb muscle reached a constant value after every stepwise change in the $\mathrm{O}_{2}$ concentration of the buffer.

\section{Analysis of data}

Changes in the $\mathrm{O}_{2}$ uptake rate were analyzed using a rectangular hyperbolic curve equation: $\mathrm{V}=\mathrm{V}_{\max }\left(\mathrm{PO}_{2} / \mathrm{P}_{\mathrm{V} 50}\right) /$ $\left\{1+\left(\mathrm{PO}_{2} / \mathrm{P}_{\mathrm{V} 50}\right)\right\}$. Here, the maximal rate of $\mathrm{O}_{2}$ uptake $\left(\mathrm{V}_{\text {max }}\right)$ and effluent buffer $\mathrm{PO}_{2}$ at half maximal $\mathrm{O}_{2}$ uptake $\left(P_{V 50}\right)$ were obtained from the slope $\left(1 / \mathrm{V}_{\max }\right)$ and the ordinate intercept $\left(\mathrm{P}_{\mathrm{V} 50} / \mathrm{V}_{\max }\right)$ of the Hanes-Woolf plot (effluent $\mathrm{PO}_{2} / \mathrm{V}$ vs. effluent $\mathrm{PO}_{2}$ ). Changes in oxygen saturation of $\mathrm{Mb}(\mathrm{Y})$ were analyzed using the Hill equation [25], $\mathrm{Y}=\mathrm{PO}_{2}{ }^{\mathrm{n}} /\left(\mathrm{PO}_{2}{ }^{\mathrm{n}}+\mathrm{P}_{\mathrm{Y} 50}{ }^{\mathrm{n}}\right)$, where $\mathrm{P}_{\mathrm{Y} 50}$ is $\mathrm{PO}_{2}$ at half saturation of $\mathrm{Mb}\left(\mathrm{Y}_{50}\right)$ and $\mathrm{n}$ is the Hill coefficient. In the original Hill equation, $\mathrm{n}$ was treated as a constant. This equation expressed the ODC of Mb well but not the ODC of $\mathrm{Hb}$ because the Hill plot for $\mathrm{Hb}$ deviated from a straight line at both extremes. To make the Hill plot applicable to $\mathrm{Hb}$, Wyman [26] extended the equation by linearizing it in the form: $\log \{\mathrm{Y} /(1-\mathrm{Y})\}=\mathrm{n}\left(\log \mathrm{PO}_{2}-\log \mathrm{P}_{\mathrm{Y} 50}\right)$ where $\mathrm{n}$ was treated as a variable. This extension allowed cooperativity measured by $\mathrm{n}$ to vary depending on $\mathrm{Y}$.

\section{Results \\ Oxygen uptake by perfused muscle in different respiration states}

Figure 2 shows the steady-state $\mathrm{O}_{2}$ uptake rate $(\mathrm{V})$ of a perfused muscle. The respiration rate of the muscle was varied by controlling mitochondrial respiration activity by about 7.5-fold (compare the $\mathrm{V}_{\max }$ values described below) from a suppressed state with an inhibitor (KCN) of mitochondrial respiration to enhanced states with two levels of an uncoupler (2,4-dinitrophenol) of mitochondrial respiration. Three preparations of muscle were used for the experiments in each mitochondrial activity state. The actual $\mathrm{PO}_{2}$ values of the influent and effluent buffers at the maximal $\mathrm{O}_{2}$ inflow rate are listed in Table 1. Changes in the value of $\mathrm{V}$ were well expressed by a rectangular hyperbolic curve as a function of effluent buffer $\mathrm{PO}_{2}$ (Fig. 2). Table 1 also gives the estimated $V_{\max }$ and $P_{V 50}$ obtained from these data as described in Materials and Methods. $\mathrm{V}_{\max }$ and $\mathrm{P}_{\mathrm{V} 50}$ became larger by approximately 7.5 -fold and 2-fold, respectively, for the maximal increase in respiration activity. With elevation of respiration activity, the critical $\mathrm{PO}_{2}$, at which $\mathrm{O}_{2}$ uptake of perfused hindlimb muscle starts to decrease, increased to higher values. This indicates that, under higher respiration activity, $\mathrm{O}_{2}$ supply 
Table 2: Linear regression parameters for Hill's plot of myoglobin oxygenation in perfused rat hindlimb muscle, log $[Y /(I-Y)]=k+$ $\mathrm{n}_{\text {app. }}$ * log [effluent $\mathrm{PO}_{2}$ ]

\begin{tabular}{|c|c|c|c|c|}
\hline Respiration state: & $\begin{array}{l}\text { Suppressed } \\
(0.4 \mathrm{mM} \mathrm{KCN})\end{array}$ & Control & $\begin{array}{l}\text { Enhanced } \\
(5 \mu \mathrm{M} \text { DNPa) }\end{array}$ & $\begin{array}{l}\text { Enhanced } \\
\text { (10 } \mu \mathrm{M} \text { DNP) }\end{array}$ \\
\hline Slope, $\mathrm{n}_{\text {app. }}{ }^{*}$ & $1.10 \pm 0.10$ & $1.46 \pm 0.06$ & $1.63 \pm 0.15$ & $1.85 \pm 0.05$ \\
\hline Intercept, $\mathrm{k}^{*}$ & $-1.36 \pm 0.13$ & $-3.08 \pm 0.13$ & $-3.75 \pm 0.34$ & $-4.43 \pm 0.12$ \\
\hline
\end{tabular}

$* 95 \%$ confidence level.

to the perfused muscle was limited even at very high influent $\mathrm{PO}_{2}$ ( $\left.700 \mathrm{mmHg}\right)$. This situation occurred because the flow rate of the perfusate and the capillary $\mathrm{PO}_{2}$ were controlled independently of the respiration activity state so that the $\mathrm{PO}_{2}$ gradient between the perfusate and the mitochondria became larger at higher respiration states.

\section{Relationship between effluent buffer $\mathrm{PO}_{2}$ and $\mathrm{Mb}$ oxygenation in perfused muscle}

Figure 3A shows ODCs for $\mathrm{Mb}$ in the perfused muscle. Here, $\mathrm{Y}$ is plotted against effluent buffer $\mathrm{PO}_{2}$. These ODCs are apparent in the sense that the $\mathrm{PO}_{2}$ is not the value at the location where $\mathrm{Mb}$ is working. The curve was shifted to the right and became steeper as muscle respiration activity was enhanced. These oxygenation data were further expressed by means of the Hill plot $(\log [\mathrm{Y} /(1-\mathrm{Y})]$ vs. $\log \mathrm{PO}_{2}$ ), yielding linear plots (Fig. 3B). The effluent buffer $\mathrm{PO}_{2}$ at half saturation $\left(\mathrm{P}_{\mathrm{Y} 50}\right)$ and the slope of the Hill plot (the Hill coefficient, $\mathrm{n}$ ) obtained from these plots are listed in Table 2, where $\mathrm{n}$ is expressed as $\mathrm{n}_{\text {app }}$ (apparent $\mathrm{n}$ ). The $\mathrm{P}_{\mathrm{Y} 50}$ value became larger with an increase in muscle respiration activity. The $\log \mathrm{P}_{\mathrm{Y} 50}$ value was nearly linearly related to the $\log P_{\mathrm{V} 50}$ value (not shown). The $\mathrm{n}_{\text {app }}$ value also increased from 1.10 in the suppressed respiration activity state to 1.85 in the 7.5 -fold enhanced respiration activity state.

Since this virtual cooperativity is of particular interest, its relation to $\mathrm{O}_{2}$ uptake rate was further examined. Figure 4 shows the dependence of $\mathrm{n}_{\mathrm{app}}$ on $\mathrm{V}$ at the half $\mathrm{O}_{2}$ saturation point of $\mathrm{Mb}\left(\mathrm{V}_{\mathrm{Y} 50}\right)$. The $\mathrm{n}_{\mathrm{app}}$ value asymptotically increased from unity for the non-respiring state to 2.23 at infinite $\mathrm{V}_{\mathrm{Y} 50}$. These results indicate that the apparent ODC of $\mathrm{Mb}$ in the perfused muscle is transformed from a hyperbolic curve to a sigmoid curve depending on the magnitude of tissue respiration. Effect of the Hill coefficient (n) on ratio of substrate (or ligand) concentrations necessary to change enzyme activity from $90 \%$ to $10 \%$ of maximal can be expressed with a parameter, $\mathrm{R}\left(=81^{1 / \mathrm{n}}\right)$ [27]. Here, the $\mathrm{O}_{2}$ transport efficiency $\left(\mathrm{EO}_{2}\right)$ was estimated as ratio of the parameter at $n_{a p p}=1$ to that at a given value of $n_{a p p}$ (Fig. 4 inset). Figure 5 shows the effect of muscle respiration on the $\mathrm{O}_{2}$ gradient between effluent and the perfused tissue. Assuming the effluent buffer $\mathrm{PO}_{2}$ approximates the capillary $\mathrm{PO}_{2}$, the calculated $\mathrm{O}_{2}$ gradient from capillary to cytoplasmic space $\left(\Delta \mathrm{PO}_{2}\right)$ is plotted against $\mathrm{V}_{\mathrm{Y} 50}$. Here, the $\mathrm{P}_{50}$ value of $\mathrm{Mb}$ in the perfused muscle was $2.3 \mathrm{mmHg}$ [21]. $\Delta \mathrm{PO}_{2}$ increased with the increase in $\mathrm{V}_{\mathrm{Y} 50}$. This result indicates the presence of a large $\mathrm{O}_{2}$ diffusion barrier between capillary lumen and cytoplasmic space.

\section{Discussion}

In the present study, by using computer-controlled rapid scanning fiber-optic spectrophotometry, I directly measured $\mathrm{Y}$ for $\mathrm{Mb}$ in isolated rat hindlimb muscles under extensive changes in respiration rate caused by mitochondrial activity control or perfusate $\mathrm{PO}_{2}$ control. It is assumed that capillary $\mathrm{PO}_{2}$ may be approximated by effluent $\mathrm{PO}_{2}$ in the present experiment, and I plotted the $\mathrm{Y}$ values as a function of effluent buffer $\mathrm{PO}_{2}$. Thereby, I expected that this treatment enabled a meaningful comparison of the ODCs for $\mathrm{Mb}$ and $\mathrm{Hb}$. I found that thus plotted apparent ODC for skeletal muscle Mb was hyperbolic under a suppressed metabolic activity condition whereas it became sigmoid under enhanced metabolic activity conditions, realizing virtually cooperative oxygenation of the monomeric Mb.

It is generally accepted that cooperative $\mathrm{O}_{2}$ binding by $\mathrm{Hb}$ is advantageous for efficient $\mathrm{O}_{2}$ transfer from the alveolar gas to red cells and from red cells to peripheral tissues. Based on the Hill equation, Graby and Meldon [28] showed that an $n$ value (here, $n$ is a constant) of 1.5 to 2.0 is more favourable for minimizing the change in blood flow under resting conditions than the normal $n$ value of 2.5 to 3.0, whereas an $n$ value as large as 3 is beneficial for a large amount of $\mathrm{O}_{2}$ extraction under vigorous exercise. Kobayashi et al. [29] showed that, under resting conditions, $\mathrm{O}_{2}$ release from $\mathrm{Hb}$ becomes most sensitive to $\mathrm{PO}_{2}$ change at $\mathrm{Y}=38 \%$ where cooperativity measured by $n$ (here, $n$ is a variable of $\mathrm{PO}_{2}$ ) is not maximal, whereas it becomes less sensitive at the mixed venous blood $\mathrm{PO}_{2}$ where $\mathrm{Y}$ is around $70 \%$ and cooperativity is nearly maximal. These reports indicate that, under resting conditions, the blood reserves an $\mathrm{O}_{2}$ transport capacity to meet possible increases in $\mathrm{O}_{2}$ demand, e.g. under exercise conditions, and the sigmoid character of ODC becomes more important under such conditions. This situation is real- 


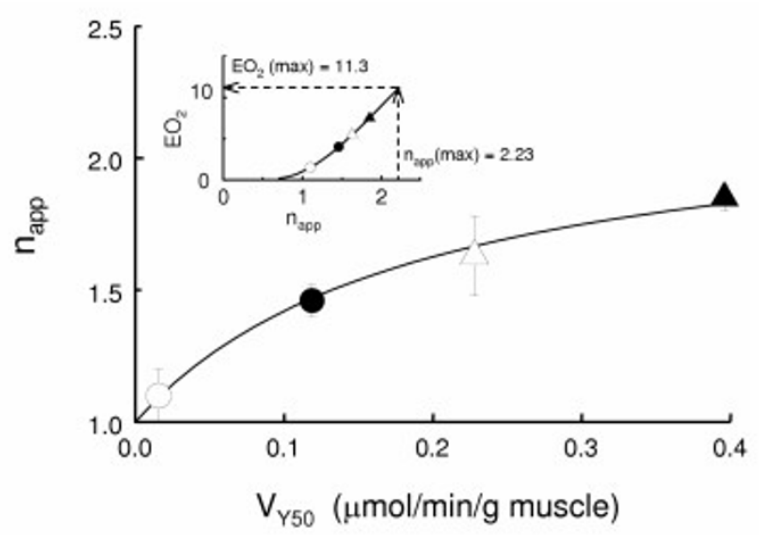

Figure 4

Relationship between $\mathrm{n}_{\text {app }}$ and steady-state $\mathrm{O}_{2}$ uptake rate at $Y=50 \%\left(V_{Y 50}\right)$. The $V_{Y 50}$ values were obtained from the hyperbolic curves in Fig. 2 . The symbols (mean \pm SD) are as in Fig. 2. The solid line, which was calculated from the equation: $\mathrm{n}_{\mathrm{app}}=\mathrm{I}+1.23 * \mathrm{~V}_{\mathrm{Y} 50} /\left(0.193+\mathrm{V}_{\mathrm{Y} 50}\right)$, simulates the observed dependence. The maximal value of $\mathrm{n}_{\mathrm{app}}$ at infinite $V_{Y 50}$ is 2.23 , which was obtained using the Hanes-Woolf plot, $\mathrm{V}_{Y 50} /\left(\mathrm{n}_{\mathrm{app}}-\mathrm{I}\right)$ vs. $\mathrm{V}_{Y 50}$. The inset figure shows the relationship between $\mathrm{n}_{\mathrm{app}}$ and $\mathrm{O}_{2}$ transport efficiency $\left(\mathrm{EO}_{2}\right)$ (see Text).

ized by maintaining $\mathrm{Y}$ at a rather high level (70\%) below which the $\mathrm{Y}$ value drops sharply upon $\mathrm{PO}_{2}$ decrease within the very steep middle portion of ODC.

The present study has clearly shown that the apparent ODC for $\mathrm{Mb}$ in intact skeletal muscle is sigmoid, the $\mathrm{n}_{\mathrm{app}}$ value being 1.46 under the control condition (Table 2) and 2.23 under the maximal respiratory condition (Fig. 4 ). These $n_{\text {app }}$ values greater than unity imply that the muscle $\mathrm{Mb}$ binds $\mathrm{O}_{2}$ in a virtually cooperative manner with variation of effluent buffer $\mathrm{PO}_{2}$. This phenomenon implies that the sensitivity of $\mathrm{Y}$ for $\mathrm{Mb}$ to vessel $\mathrm{PO}_{2}$ change becomes higher for increased $\mathrm{O}_{2}$ demands than for normal $\mathrm{O}_{2}$ demand. In addition to this effect, the rightward shift of the ODC upon increases in oxygen demand will undoubtedly enhance $\mathrm{O}_{2}$ unloading from $\mathrm{Mb}$. These effects will facilitate $\mathrm{Mb}$-mediated $\mathrm{O}_{2}$ transfer from $\mathrm{Hb}$ to Cyt. $\mathrm{aa}_{3}$, especially for heavy $\mathrm{O}_{2}$ demands. Based on the Hill equation, the $\mathrm{O}_{2}$ transport efficiency of $\mathrm{Mb}$ in the perfused muscle is estimated to increase ca. 4-fold under the control condition and ca. 11-fold under maximally respiring condition (Fig. 4 inset).

The Mbs isolated from body wall or radular muscle of a limited number of annelidan and molluscan species are dimers and show some cooperativity in oxygen binding (1 $<\mathrm{n}<2$ ) but no Bohr effect [30]. The physiological signif- icance of these dimeric Mbs is unknown. As shown in the present study, the ODC of monomeric Mb can exhibit virtual cooperativity and $\mathrm{O}_{2}$ demand-dependent shifts. The virtually cooperativity and $\mathrm{O}_{2}$ demand-dependent shifts of $\mathrm{Mb}$ oxygenation in vivo are probably common features at least for vertebrate Mbs, and this may provide a basis for explaining why the vertebrate $\mathrm{Mb}$ has been preserved as a monomer during molecular evolution.

The virtual cooperativity in $\mathrm{Mb}$ oxygenation observed in the present study is explained in terms of the $\mathrm{PO}_{2}$ gradient along the $\mathrm{O}_{2}$ diffusion path. If the tissue $\mathrm{O}_{2}$ demand was null, then the $\mathrm{PO}_{2}$ gradient would be absent and the apparent ODC for $\mathrm{Mb}$ would be identical with the real ODC for $\mathrm{Mb}$ in solution. At a steady state with a certain level of $\mathrm{O}_{2}$ demand a $\mathrm{PO}_{2}$ gradient develops across red cell membrane, blood plasma, capillary wall, sarcolemma and sarcoplasm, making the $\mathrm{PO}_{2}$ sensed by $\mathrm{Mb}$ lower than the capillary $\mathrm{PO}_{2}$. Then, the apparent $\mathrm{ODC}$ will be shifted toward the right because a capillary $\mathrm{PO}_{2}$ value higher than the $\mathrm{PO}_{2}$ value sensed by $\mathrm{Mb}$ is needed to maintain the same $\mathrm{Y}$ value as that which occurs in the absence of $\mathrm{aPO}_{2}$ gradient. When the tissue $\mathrm{O}_{2}$ demand is kept constant, the ratio of capillary $\mathrm{PO}_{2}$ to sarcoplasm $\mathrm{PO}_{2}$ will become larger at low capillary $\mathrm{PO}_{2}$ than at high capillary $\mathrm{PO}_{2}$. This will cause a more extensive rightward shift of the apparent ODC in the low saturation range than in the high saturation range, making the curve steeper than the real one. Increase in tissue oxygen demand will enhance this mechanism and make the curve more right-shifted and sigmoid. All the apparent ODCs observed in the present study are shifted toward the right compared to the real one measured for $\mathrm{Mb}$ in solution (Fig. 3).

At present, detailed explanations for this cooperative mechanism is difficult. However, it could be argued that heterogeneous oxygenation in tissue [31] and in single myocytes [32] might be responsible in part for the shift and the shape change of the Mb ODC, and might also enhance intercellular $\mathrm{O}_{2}$ transfer, i.e., re-distribution of $\mathrm{O}_{2}$ among adjacent myocytes, although we adopted high and constant flow rate perfusion conditions (i.e., about 50 times higher than normal blood flow) and, thus, the perfused vessels of muscle were always passively dilated.

Unfortunately, it is not practical to use a Hb solution or a red cell suspension as the perfusate in our experiments because the absorption spectra for $\mathrm{Hb}$ and $\mathrm{Mb}$ are too similar and independent observations of $\mathrm{Mb}$ oxygenation are not feasible, especially when the concentration of $\mathrm{Hb}$ is much higher than that of $\mathrm{Mb}$. To overcome the problem that the $\mathrm{O}_{2}$ solubility of the buffer is much smaller than that of a Hb solution or a red cell suspension two strategies were employed: one was to make the $\mathrm{PO}_{2}$ of the influent buffer as high as that of water vapor-saturated $\mathrm{O}_{2}$ (ca. 


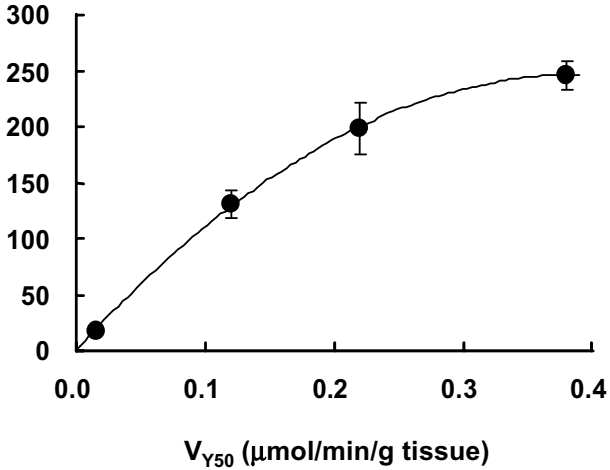

\section{Figure 5}

Correlation between $\mathrm{O}_{2}$ consumption at $50 \%$ of Mb oxygenation $\left(\mathrm{V}_{\mathrm{Y} 50}\right)$ and calculated $\mathrm{O}_{2}$ gradient from vascular to cytoplasmic space in perfused hindlimb muscle $\left(\Delta \mathrm{PO}_{2}\right)$. To calculate $\Delta \mathrm{PO}_{2}, \mathrm{PO}_{2}=2.3 \mathrm{mmHg}$ at $\mathrm{Y}=50 \%$ of $\mathrm{Mb}$ in the perfused muscle was used [2I]. $\Delta \mathrm{PO}_{2}=-1635 * \mathrm{~V}_{Y_{50}}+1269$ $\left(r^{2}=0.9995\right)$.

$700 \mathrm{mmHg}$ ) and the other was to use a high flow rate for the buffer, which was about 50 times higher than that of normal blood flow. As a result, the inflow of $\mathrm{O}_{2}$ was about 5 times larger than that of the tissue $\mathrm{O}_{2}$ consumption at the control metabolic rate. The large $\mathrm{O}_{2}$ diffusion barrier (see Fig. 5) and the high $\mathrm{PO}_{2}$ of the influent buffer (and consequently, the high capillary $\mathrm{PO}_{2}$ ) are an additional (and probably, major) cause for the rightward shift of the apparent ODC of $\mathrm{Mb}$. The apparent ODCs of $\mathrm{Mb}$ in the control and enhanced respiration activity states (Fig. 3A) are right-shifted compared to the whole blood ODC (Fig. 1 ). One may suppose that Mb cannot work when the capillary $\mathrm{PO}_{2}$ is in the physiological range (40 to100 $\mathrm{mmHg}$ ) because its $\mathrm{O}_{2}$ saturation is too low to function, as judged from Fig. 3A. However, the actual apparent ODCs for Mb in muscles with blood circulation will be shifted much more toward the left compared to those shown in Fig. 3A, and $\mathrm{Mb}$ can be saturated with $\mathrm{O}_{2}$ to practical levels. The important point is that the difference in in vivo $\mathrm{O}_{2}$ saturation between $\mathrm{Hb}$ and $\mathrm{Mb}$ is not so large as that expected from the ODCs in Fig. 1. In fact, Y for Mb in working muscles is less than around 50\% [19,20,31-33]. Red blood cell (RBC) in perfusion buffer appears to exert considerable effects on intracellular oxygenation in the beating heart [34], probably due to the facilitated $\mathrm{O}_{2}$ transfer by $\mathrm{RBC}$ motion within capillary lumen [35]. Therefore, the virtually cooperative oxygenation of $\mathrm{Mb}$ might be only demonstrated in organs perfused with RBC-free medium. However, it is well known that the blood flow in the capillary bed is not constant and frequently only plasma flow is observed. In this case, the virtually cooperative oxygenation of $\mathrm{Mb}$ may play a significant role for $\mathrm{O}_{2}$ transfer from capillary to mitochondria.

In summary, I found that the ODC for $\mathrm{Mb}$ in intact skeletal muscle is sigmoid and right-shifted. This virtually cooperative $\mathrm{O}_{2}$ binding by $\mathrm{Mb}$ and the right-shift of ODC become more marked as tissue respiration activity is increased. Hence, increase in $\mathrm{O}_{2}$ demand in tissues makes the $\mathrm{O}_{2}$ saturation of $\mathrm{Mb}$ more sensitive to capillary $\mathrm{PO}_{2}$ change and enhances $\mathrm{Mb}$-mediated $\mathrm{O}_{2}$ transfer from red cell to motochondria. The virtual cooperativity and $\mathrm{O}_{2}$ demand-dependent shifts of ODC may give a basis for explaining why $\mathrm{Mb}$ has been preserved as a monomer during molecular evolution. Preservation of a monomeric structure may be required to retain multi-functional role of $\mathrm{Mb}$ in vivo.

\section{Acknowledgements}

This work was supported in part by a research grant from the Ministry of Education, Science and Culture of Japan.

\section{References}

I. Kagen LJ: Myoglobin New York, London: Columbia University Press; 1973.

2. Millikan GA: Experiments on muscle haemoglobin in vivo; the instantaneous measurement of muscle metabolism. Proc $R$ Soc Lond B Biol Sci 1937, I 23:2 I8-24I.

3. Millikan GA: Muscle hemoglobin. Physiol Rev 1939, 19:503-523.

4. Wyman J: Facilitated diffusion and the possible role of myoglobin as a transport mechanism. J Biol Chem 1966, 24I:II5-I2I.

5. Wittenberg JB: Oxygen transport: a new function proposed for myoglobin. Biol Bull 1959, I I 7:402-403.

6. Scholander PF: Oxygen transport through hemoglobin solutions. Science 1960, I3 1:585-590.

7. Wittenberg JB: Myoglobin-facilitated oxygen diffusion: Role of myoglobin in oxygen entry into muscle. Physiol Rev 1970, 50:559-636

8. Jones DP, Kennedy FG: Intracellular $\mathbf{O}_{2}$ gradients in cardiac myocytes. Lack of a role for myoglobin in facilitation of intracellular diffusion. Biochem Biophys Res Commun 1982, 1 05:4 I9-424.

9. Kennedy FG, Jones DP: Oxygen dependence of Mitochondrial function in isolated rat cardiac myocytes. Am J Physiol 1986, 250:C374-C383.

10. Livingston DJ, LaMar GN, Brown WD: Myoglobin diffusion in bovine heart muscle. Science 1983, 220:71-73.

II. Jurgens KD, Peters T, Gros G: Diffusivity of myoglobin in intact skeletal muscle cells. Proc Natl Acad Sci USA 1994, 91:3829-3833.

12. Paradopoulos S, Jurgens KD, Gros G: Diffusion of myoglobin in skeletal muscle cells-dependence on fiber type, contraction and temperature. Pflugers Arch 1995, 430:519-525.

13. Doeller JE, Wittenberg BA: Myoglobin function and energy metabolism of isolated cardiac myocytes: effect of sodium nitrite. Am J Physiol I99I, 26I:H53-H62.

14. Garry DJ, Meeson A, Yan Z, Williams RS: Life without myoglobin. Cell Mol Life Sci 2000, 57:896-898.

15. Garry DJ, Ordway GA, Lorenz JN, Radford NB, Chin ER, Grange RW, Bassel-Duby R, Williams RS: Mice without myoglobin. Nature 1998, 395:905-908.

16. Godecke A, Flogel U, Zanger K, Ding Z, Hirchenhain J, Decking UKM, Schrader J: Disruption of myoglobin in mice induces multiple compensatory mechanisms. Proc Natl Acad Sci USA 1999, 96:10495-10500.

17. Burmester T, Weich B, Reinhardt S, Hankeln T: A vertebrate globin expressed in the brain. Nature 2000, 407:520-523. 
18. Giardina B, Ascenzi P, Clementi ME, De Sanctis G, Rizzi M, Coletta M: Functional modulation by lactate of myoglobin. J Biol Chem I996, 27 I: I6999-I700I.

19. Mole PA, Chung Y, Tran T-K, Sailusuta N, Hurd R, Jue T: Myoglobin desaturation with exercise intensity in human gastrocnemius muscle. Am J Physiol 1999, 277:RI73-RI80.

20. Richardson RS, Noyszewski RA, Kendrick KF, Leigh JS, Wagner PD: Myoglobin $\mathrm{O}_{2}$ desaturation during exercise. Evidence of limited $\mathbf{O}_{2}$ transport. J Clin Invest 1995, 96:1916-1926.

21. Seiyama A, Maeda N, Shiga T: Optical measurement of perfused rat hindlimb muscle with relation of oxygen metabolism. Jpn J Physiol 1991, 41:49-61.

22. Seiyama A, Kosaka H, Maeda N, Shiga T: Effect of hypothermia on skeletal muscle metabolism in perfused rat hindlimb. Cryobiology 1996, 33:338-346.

23. Ruderman NB, Houghton CRS, Hems R: Evaluation of the isolated perfused rat hindquarter for the study of muscle metabolism. Biochem J I97I, I 24:639-65I.

24. Shiota $T$, Sugano $M$ : Characteristics of rat hindlimbs perfused with erythrocyte- and albumin-free medium. Am J Physiol 1986, 25 I:C78-C84.

25. Hill AV: The possible effects of the aggregation of the molecules of haemoglobin on its dissociation curves. J Physiol 1910, 40:4-7.

26. Wyman J: Linked functions and reciprocal effects in hemoglobin: A second look. Advan Protein Chem 1964, 19:223-286.

27. Taketa K, Pogell BM: Allosteric inhibition of rat liver fructose I,6-diphospatase by adenosine 5'-monophosphate. J Biol Chem 1965, 240:651-662.

28. Garbyb L, Meldon J: The Respiratory Functions of Blood New York, London: Plenum Medical Book; 1977.

29. Kobayashi M, Kimura S, Ishigaki KI, Makino N, Imai K: Significance of oxygen affinity of fetal and adult human hemoglobins. Zool Sci 1996, 13:661-664.

30. Suzuki T, Imai K: Evolution of myoglobin. Cell Mol Life Sci I998, 54:979-1004.

31. Gayeski TEJ, Honig CR: $\mathbf{O}_{2}$ gradients from sarcolemma to cell interior in red muscle at maximal $\mathbf{V o}_{2}$. Am J Physiol 1986, $25 \mathrm{I}: \mathrm{H} 789-\mathrm{H} 799$.

32. Takahashi E, Doi K: Regulation of oxygen diffusion in hypoxic isolated cardiac myocytes. Am J Physiol 1996, 27 I:HI734-HI738.

33. Wittenberg BA, Wittenberg JB: Transport of oxygen in muscle. Annu Rev Physiol 1989, 5 I:857-878.

34. Schenkman KA, Beard DA, Ciesielski WA, Feigl EO: Comparison of buffer and red blood cell perfusion of guinea pig heart oxygenation. Am J Physiol 2003, 285:HI8I9-1825.

35. Seiyama A, Shiga T: Oxygen transfer in peripheral organs: Researches on intact organs with optical techniques. Adv Exerci Sports Physiol 1998, 4:37-49.

36. Imai K: Oxygen transport and its regulation. Rinsho Kensa (in Japanese) 1986, 30:363-37I.

\section{Publish with Bio Med Central and every scientist can read your work free of charge}

"BioMed Central will be the most significant development for disseminating the results of biomedical research in our lifetime. "

Sir Paul Nurse, Cancer Research UK

Your research papers will be:

- available free of charge to the entire biomedical community

- peer reviewed and published immediately upon acceptance

- cited in PubMed and archived on PubMed Central

- yours - you keep the copyright
BioMedcentral 